Part of Journal of Research of the National Bureau of Standards, Volume 29, July 1942

\title{
ACCELERATED AGING OF LACE LEATHERS
}

\author{
By Joseph R. Kanagy and Philip E. Tobias
}

\section{ABSTRACT}

Alum-, indian-, and chrome-tanned lace leathers, submitted by various manufacturers, were tested for deterioration under accelerated-aging conditions. In addition, the physical and chemical properties of these leathers were determined according to the tests prescribed by the Federal specification for lace leathers. The alum-tanned lace leathers were much less stable under the conditions of accelerated aging than the indian- and chrome-tanned leathers. Several types of chrome-tanned leathers, including chrome-tanned lace leather, showed intermediate stability. From the results of these tests, it appears that measurements of physical properties such as strength, stretch, and flexibility, together with an accelerated-aging test, may be expected to give more valuable information about the performance characteristics of lace leathers than the measurements required by the present Federal specification.

\section{CONTENTS}

Page

I. Introduction

II. Materials and experimental procedure

III. Results and discussion

IV. References_._.

\section{INTRODUCTION}

Two of the more important physical properties desired for lace leathers are high strength and high flexibility. These properties are found in leathers which have been tanned lightly, with the hides in an unswollen condition, followed by treatment with large amounts of oils and greases in the finishing processes. Another essential property for lace leather, as well as for any other type of leather, is durability. Durability is not necessarily imparted by the same tanning processes which yield high strength and high flexibility. Therefore, it is important that specifications for lace leathers should require a direct determination of their aging characteristics.

In the Federal specification for lace leather, KK-L-201, durability is judged from a number of chemical tests. To make these tests requires considerable time, and the significance of some of them has been questioned. An accelerated-aging test would be a more accurate index of the durability, since such a test would approximate the conditions of actual service, and would also save time in testing and simplify 
such specifications. For this reason, a study of the acceleratedaging properties of alum-, indian-, ${ }^{1}$ and chrome-tanned lace leathers was made. Methods were used which were developed at the National Bureau of Standards [1] ${ }^{2}$, and these have been shown to give results similar to those obtained with vegetable-tanned leathers under normal aging conditions.

\section{MATERIALS AND EXPERIMENTAL PROCEDURE}

The samples tested included indian-, alum-, and chrome-tanned lace leathers. A total of 15 samples of these leathers were submitted by various manufacturers, and it was assumed that they were fairly representative of the lace leather on the market.

From each block, measuring 7 by 14 inches, 12 tensile-strength specimens were cut. These blocks were cut from the best area of the hide available, however, no regard was given to using the corresponding areas from all of the hides in a given test. The specimens were numbered 1 to 12 , consecutively. The even-numbered specimens were aged, whereas the odd-numbered ones were used as controls. In all but one experiment the samples were allowed to dry for 6 hours before aging. This drying procedure is described in a previous publication [1]. The effect of degreasing before aging on some of the samples was also studied.

The apparatus used in making the tests was the same as that described in a previous publication [1]. Air which had been saturated with water at $45^{\circ} \mathrm{C}$ was passed over the leather specimens. This furnished an atmosphere having a relative humidity of about 9.5 percent at $100^{\circ} \mathrm{C}$. The temperature and time of aging were varied.

\section{RESULTS AND DISCUSSION}

The results of the accelerated-aging tests on the lace leathers, expressed as percentage loss in breaking strength, are given in table 1. The temperature, time, and other conditions of aging are also given. The results indicate that the alum-tanned lace leathers are extremely unstable under all of the aging conditions. The relative order of stability of each of the alum-tanned leathers is the same for nearly all sets of conditions tried. Alum leather 6 is most stable under all conditions; alum leather 4 is correspondingly least stable. Degreasing the leathers decreases the rate of deterioration, but the relative rates of deterioration are unchanged.

Indian- and chrome-tanned lace leathers are much more resistant to accelerated aging than the alum-tanned leathers, as shown in table 1. In these cases, as was also observed with alum leathers, the relative order of resistance to aging as measured by loss in breaking strength for each of the samples is the same under nearly all of the conditions. Leathers 1 and 14 are most resistant to aging, whereas leather 10 is least resistant. The chrome-tanned lace leathers show comparatively low resistance to aging. Chrome leather 11 gives a high percentage loss in breaking strength in comparison with any of the indian-tanned leathers, whereas chrome lace leather 15 is equal in performance to the indian-tanned leathers, which give intermediate results.

\footnotetext{
1 Alum-tanned leather retanned with a suitable vegetable tanning material.

2 Figures in brackets indicate the literature references at the end of this paper.
} 
TABLE 1.-Results of accelerated aging

Percentage loss in breaking strength

\begin{tabular}{|c|c|c|c|c|c|c|}
\hline \multirow[b]{2}{*}{ Leather number } & \multicolumn{6}{|c|}{ Conditions of aging-air saturated with water vapor at $45^{\circ} \mathrm{C}$} \\
\hline & $\begin{array}{l}100^{\circ} \mathrm{C} ; \\
7 \text { days; } \\
\text { dried }\end{array}$ & $\begin{array}{l}90^{\circ} \mathrm{C} ; \\
4 \text { days; } \\
\text { dried }\end{array}$ & $\begin{array}{l}90^{\circ} \mathrm{C} \\
2 \text { days; } \\
\text { dried }\end{array}$ & $\begin{array}{l}80^{\circ} \mathrm{C} ; \\
4 \text { days; } \\
\text { dried }\end{array}$ & $\begin{array}{c}90^{\circ} \mathrm{C} ; 4 \\
\text { days; dried; } \\
\text { degreased }\end{array}$ & $\begin{array}{c}100^{\circ} \mathrm{C} ; \\
7 \text { days; } \\
\text { not dried }\end{array}$ \\
\hline
\end{tabular}

ALUM-TANNED

\begin{tabular}{|c|c|c|c|c|c|c|}
\hline $9^{2}$ & $\begin{array}{l}88 \\
95 \\
81\end{array}$ & $\begin{array}{r}74 \\
89 \\
65 \\
-\end{array}$ & $\begin{array}{l}57 \\
80 \\
51 \\
72\end{array}$ & $\begin{array}{l}66 \\
81 \\
60 \\
66\end{array}$ & $\begin{array}{l}64 \\
69 \\
41 \\
43\end{array}$ & 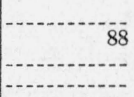 \\
\hline
\end{tabular}

INDIAN-TANNED

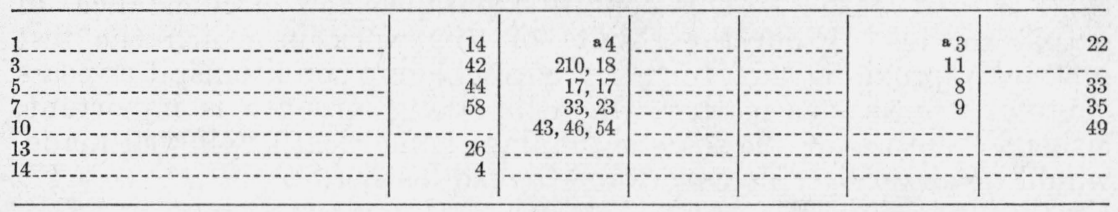

CHROME-TANNED

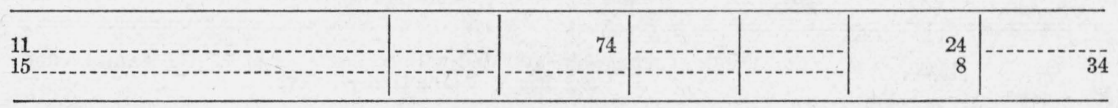

a Gain.

Since the low resistance to aging of the chrome lace leathers was unexpected, several additional experiments were made, in which other types of chrome-tanned leathers were included. Chrometanned ski leather, chrome-tanned lace leather, and chrome-, chestnut-, and quebracho-tanned steer-hide leathers were aged at $60^{\circ}$, $70^{\circ}, 80^{\circ}, 90^{\circ}$, and $100^{\circ} \mathrm{C}$ in air which had been saturated with water at $60^{\circ} \mathrm{C}$, thus producing a relative humidity of approximately 19.5 percent at $100^{\circ} \mathrm{C}$. Chrome-tanned steer hide, chrome-tanned lace leather, and chrome-tanned ski-leather, previously dried, were aged at $80^{\circ}, 100^{\circ}$, and $120^{\circ} \mathrm{C}$ in air saturated with water at $45^{\circ} \mathrm{C}$. The steerhide leathers were tanned in the experimental tannery at the National Bureau of Standards.

The results of the accelerated aging are shown in table 2 , and in comparing the losses in breaking strength, the chrome-tanned leathers show less stability under the conditions of this test than quebracho leather and are about equal in stability to chestnut leather. The losses in breaking strength, for the chrome-tanned leathers, increase with temperature, continuing up to $120^{\circ} \mathrm{C}$, the highest temperature at which the tests were made. Slightly higher losses in breaking strength were obtained at $60^{\circ}$ than at $70^{\circ} \mathrm{C}$. This was possibly caused by the condition of 100 -percent relative humidity at $60^{\circ} \mathrm{C}$. The amounts of soluble nitrogenous materials extractable by a $0.1 \mathrm{~N}$ sodium carbonate solution from the aged chrome-tanned leathers do not parallel the losses in breaking strength. The aged samples yield small amounts of soluble nitrogenous materials, which are nearly constant for every temperature except $120^{\circ} \mathrm{C}$. Similar results for losses in breaking strength and for amounts of soluble nitrogenous materials for chrome-tanned leathers were obtained by Frey and 
Beebe [4] in their studies on acid deterioriation in the sulfur dioxide gas chamber. They suggested that the soluble nitrogenous material values might not be a reliable index of the deterioration of chrometanned leathers and also mentioned the possibility of a mechanism of deterioration, different for chrome- than for vegetable-tanned leathers. The fact that a mechanism of deterioration, different for chrome- than for vegetable-tanned leathers, may exist emphasizes the importance of the selection of suitable conditions and the proper criterion of deterioration for comparing the aging qualities of vegetable- and chrome-tanned leathers. The conditions of aging should be similar to those which the leathers will undergo in service. The belief that chrome leather is superior to vegetable-tanned leather originated principally from the fact that well-tanned chrome leather when heated in water has a higher shrinkage temperature than vegetable-tanned leather. This condition parallels few circumstances of actual service. From the results of this work in which the test method approximates more nearly normal aging conditions, it appears that for use as lace leather, where breaking strength is important, either vegetable- or the so-called indian-tanned leather, if well made, would be as serviceable as chrome-tanned leather.

TABLE 2.-Results of accelerated aging tests

\begin{tabular}{|c|c|c|c|c|c|c|c|c|c|c|}
\hline \multirow{3}{*}{ Type of leather } & \multicolumn{10}{|c|}{$\begin{array}{l}\text { Conditions of aging-air saturated with water vapor at } 60^{\circ} \mathrm{C} \text {. Samples not } \\
\text { dried. Aging time-7 days }\end{array}$} \\
\hline & \multirow{2}{*}{ 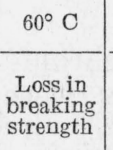 } & \multirow{2}{*}{\multicolumn{2}{|c|}{$\frac{70^{\circ} \mathrm{C}}{\begin{array}{c}\text { Loss in } \\
\text { breaking } \\
\text { strength }\end{array}}$}} & \multicolumn{3}{|c|}{$80^{\circ} \mathrm{C}$} & \multicolumn{2}{|c|}{$90^{\circ} \mathrm{C}$} & \multicolumn{2}{|c|}{$100^{\circ} \mathrm{C}$} \\
\hline & & & & $\begin{array}{l}\text { Loss } \\
\text { breaki } \\
\text { streng }\end{array}$ & $\begin{array}{l}\text { in } \\
\text { ing } \\
\text { gth }\end{array}$ & $\begin{array}{l}\text { Solu- } \\
\text { ble ni- } \\
\text { trogen }\end{array}$ & $\begin{array}{l}\text { Loss in } \\
\text { breaking } \\
\text { strength }\end{array}$ & $\begin{array}{l}\text { Solu- } \\
\text { ble ni- } \\
\text { trogen }\end{array}$ & $\begin{array}{l}\text { Loss in } \\
\text { breaking } \\
\text { strength }\end{array}$ & $\begin{array}{l}\text { Solu- } \\
\text { ble ni- } \\
\text { trogen }\end{array}$ \\
\hline \multirow[t]{4}{*}{$\begin{array}{l}\text { Quebracho-tanned steer } \\
\text { hide- } \\
\text { Chestnut-tanned steer hide } \\
\text { Chrome-tanned steer hide } \\
\text { Chrome-tanned lace. } \\
\text { Chrome-tanned ski.... }\end{array}$} & \begin{tabular}{rr|}
$\%$ & \\
& 5 \\
6 \\
8 \\
8 \\
& 6
\end{tabular} & \multicolumn{2}{|c|}{$\begin{array}{ll}\% & \\
& 2 \\
& 3 \\
& 7 \\
& 0\end{array}$} & \multicolumn{2}{|c|}{$\begin{array}{r}\% \\
9 \\
13 \\
10 \\
10,15\end{array}$} & $\begin{array}{c}\% \\
1.0 \\
4.0 \\
0.6 \\
.6 \\
1.5\end{array}$ & $\begin{array}{r}\% \\
9 \\
24 \\
20 \\
27 \\
15\end{array}$ & \begin{tabular}{l|}
$\%$ \\
1.0 \\
6.4 \\
1.0 \\
0.7 \\
.6
\end{tabular} & $\begin{array}{r}\% \\
16 \\
29 \\
31 \\
34 \\
26\end{array}$ & $\begin{array}{r}\% \\
1.5 \\
11.0 \\
0.9 \\
1.0 \\
1.1\end{array}$ \\
\hline & \multicolumn{10}{|c|}{$\begin{array}{c}\text { Conditions of aging - air saturated with water vapor at } 45^{\circ} \mathrm{C} \text {. Samples } \\
\text { dried. Aging time }-7 \text { days }\end{array}$} \\
\hline & \multicolumn{4}{|c|}{$80^{\circ} \mathrm{C}$} & \multicolumn{3}{|c|}{$100^{\circ} \mathrm{C}$} & \multicolumn{3}{|c|}{$120^{\circ} \mathrm{C}$} \\
\hline & \multicolumn{2}{|c|}{$\begin{array}{l}\text { Loss in } \\
\text { breaking } \\
\text { strength }\end{array}$} & \multicolumn{2}{|c|}{$\begin{array}{l}\text { Soluble } \\
\text { nitrogen }\end{array}$} & \multicolumn{2}{|c|}{$\begin{array}{l}\text { Loss in } \\
\text { breaking } \\
\text { strength }\end{array}$} & $\begin{array}{l}\text { Soluble } \\
\text { nitrogen }\end{array}$ & \multicolumn{2}{|c|}{$\begin{array}{l}\text { Loss in } \\
\text { breaking } \\
\text { strength }\end{array}$} & $\begin{array}{l}\text { Soluble } \\
\text { nitrogen }\end{array}$ \\
\hline $\begin{array}{l}\text { Chrome-tanned steer hide. } \\
\text { Chrome-tanned lace b-..- } \\
\text { Chrome-tanned ski }\end{array}$ & $\%$ & $\begin{array}{r}\text { a } 3 \\
7 \\
8\end{array}$ & & $\begin{array}{r}0.6 \\
.6 \\
.4\end{array}$ & & $\begin{array}{ll}\% & \\
& 26 \\
& 32 \\
& 29\end{array}$ & $\%$ & & $\begin{array}{ll}\% & \\
51 \\
70 \\
70\end{array}$ & $\begin{array}{ll}\% & \\
& 2.0 \\
& 7.1 \\
& 6.7\end{array}$ \\
\hline
\end{tabular}

a Gain.

Degreased.

The chemical and physical analyses of the lace leathers are shown in table 3. These analyses were made by the methods described in Federal Specification KK-L-201 for lace leathers. Tensile-strength measurements were made in a tension machine, using the full-length lace. The degree of tannáge of the indian-tanned lace leathers was determined by the ALCA method for vegetable-tanned leathers. 
Wallace [2] has shown that the amount of the nitrogenous materials extractable from vegetable-tanned leathers decreases as the degree of tannage increases. In general, such a trend is shown by comparing the corresponding values for these factors given in table 3 . There is no apparent correlation between the results of the aging tests and the amounts of the nitrogenous materials extractable from the unaged leathers by water at $70^{\circ} \mathrm{C}$. Leather 3 , which yields far more nitrogenous material than the other indian-tanned leathers, shows as much resistance to aging as leathers 5 or 7 , and considerably more than 10. Leather 3 contains a high amount of $\mathrm{R}_{2} \mathrm{O}_{3}$, consisting: principally of aluminum oxide. Frey and Beebe [3] have shown that leathers tanned with a combination of alum and vegetable tanning materials are more resistant to aging than those tanned with vegetable tanning materials alone. They found that the resistance to aging increases as the alum content is increased. Therefore, the amounts of nitrogenous materials extractable from any unaged leathers at $70^{\circ} \mathrm{C}$ may not be a reliable criterion of the stability of those tanned with a combination of alum and vegetable tanning materials.

TABLE 3.-Properties of lace leather

\begin{tabular}{|c|c|c|c|c|c|c|c|c|c|c|c|c|c|}
\hline \multirow[b]{2}{*}{$\begin{array}{l}\text { Leather } \\
\text { number }\end{array}$} & \multicolumn{7}{|c|}{ Chemical } & \multicolumn{6}{|c|}{ Physical } \\
\hline & Ash & Grease & $\mathrm{R}_{2} \mathrm{O}_{3}$ & $\begin{array}{c}\text { Ex- } \\
\text { tracta- } \\
\text { ble } \\
\text { nitro- } \\
\text { gen }\end{array}$ & $\mathrm{Cr}_{2} \mathrm{O}_{3}$ & $\mathrm{pH}$ & $\begin{array}{l}\text { De- } \\
\text { gree } \\
\text { of } \\
\text { tan- } \\
\text { nage }\end{array}$ & $\begin{array}{c}\text { Hide } \\
\text { area }\end{array}$ & $\begin{array}{c}\text { Maxi- } \\
\text { mum } \\
\text { thick- } \\
\text { ness }\end{array}$ & $\begin{array}{c}\text { Stretch } 1 \\
1 / 4 \text { in. }\end{array}$ & $\begin{array}{c}\text { Stretch } 2 \\
\text { 1/2 in. }\end{array}$ & $\begin{array}{l}\text { Break } \\
\text { load } \\
1 / 4 \mathrm{in} .\end{array}$ & $\begin{array}{l}\text { Break } \\
\text { load } \\
1 / 2 \text { in. }\end{array}$ \\
\hline
\end{tabular}

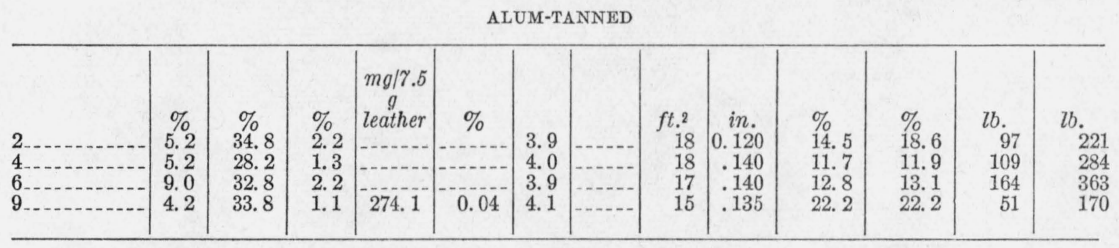

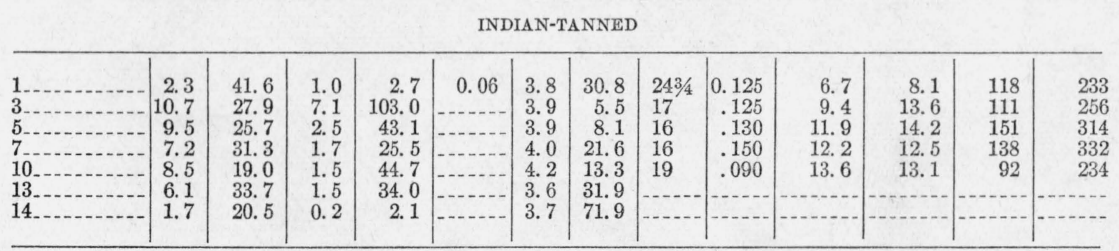

CHROME-TANNED

\begin{tabular}{|c|c|c|c|c|c|c|c|c|c|c|c|c|c|}
\hline 11 & $\begin{array}{l}5.5 \\
5.2\end{array}$ & $\begin{array}{l}24.7 \\
21.7\end{array}$ & $\begin{array}{r}0.3 \\
.5\end{array}$ & $\begin{array}{r}2.3 \\
-\end{array}$ & $\begin{array}{l}4.8 \\
2.8\end{array}$ & $\begin{array}{l}4.3 \\
3.9\end{array}$ & - & 19 & $\begin{array}{r}0.160 \\
.142\end{array}$ & $\begin{array}{l}16.1 \\
16.7\end{array}$ & $\begin{array}{l}20.0 \\
19.7\end{array}$ & $\begin{array}{r}121 \\
89\end{array}$ & $\begin{array}{l}314 \\
206\end{array}$ \\
\hline
\end{tabular}

1 Measured at $32.5 \mathrm{lb}$.

2 Measured at $85 \mathrm{lb}$.

By accelerated aging, and by the determination of the physical properties, leather 1 appears to be the best type of lace leather. It was completely penetrated with vegetable tanning materials at the low degree of tannage of 30.8. Leather 14 also resisted aging well but had a high degree of tannage, which, for most leathers, would result in a decrease of strength and flexibility. 
The determination of extractable nitrogenous materials may be misleading, especially in the case of indian-tanned leathers. It has been shown previously [1] that the $\mathrm{pH}$ of the leather is reflected in the results obtained in this accelerated-aging test. A limit of the $\mathrm{R}_{2} \mathrm{O}_{3}$ content in the Federal specification appears to be undesirable, since it has been shown that the aging resistance of combination alum- and vegetable-tanned leathers increases with the aluminum oxide content. The significance of a limit on the ash content is also open to question. From these observations and the results of this work, it appears that measurements of such physical properties as strength, stretch, and flexibility, together with an accelerated-aging test, may be expected to give more valuable information about the performance characteristics of lace leathers than the measurements required by present Federal specification.

\section{REFERENCES}

[1] J. Research NBS $\mathbf{2 5}, 149$ (1940) RP1319; J. Am. Leather Chem. Assn. 35, $632(1940)$.

[2] J. Am. Leather Chem. Assn. 26, 545 (1931).

[3] J. Am. Leather Chem. Assn. 35, 440 (1940).

[4] J. Am. Leather Chem. Assn. 29, 489 (1940).

Washington, May 12, 1942. 